\title{
MODELING AND ANALYSIS OF GROUND SETTLEMENT BETWEEN A FLYOVER AND REINFORCED SOIL EMBANKMENT
}

\section{BUKOWSKI ${ }^{1}$, P. LYSIAK ${ }^{2}$, R. OLESZEK ${ }^{3}$, W. TROCHYMIAK ${ }^{4}$}

\begin{abstract}
Development of the transport infrastructure in Poland has contributed to the implementation of various technologies of construction of bridges and their components. Use of reinforced soil for construction of embankments, retaining structures (RSS walls) and abutments is one of the solutions which has been frequently used for the past twenty years. Shortly after its development, the technology proposed by Henri Vidal in 1966 also gained appreciation in Poland [4]. Reinforced soil bridge abutments started to be widely used in Poland at the turn of the $20^{\text {th }}$ century. The bridge facilities at the junction of Trasa Siekierkowska route and Wał Miedzeszyński Street in Warsaw, which were built in the years $2000 \div 2002$, are an example of structures from that period. The authors of this paper have been particularly interested in the outermost supports of the reinforced concrete flyovers which were constructed in the form of intermediate reinforced soil abutments. Offsets - the vertical displacements, in the range of $15 \div 25 \mathrm{~mm}$, emerging between the level of the road surface and the steel elements of the expansion joints which separate the flyover's structure from the embankment - were observed in 2015, in the course of regular inspections. While accounting for the observations which have been made, the surveying measurements
\end{abstract}

${ }^{1}$ PhD., Eng., Warsaw University of Technology, Faculty of Civil Engineering, ul. Lecha Kaczyńskiego 16, 00-637 Warsaw, Poland, e-mail: miroslaw.bukowski@il.pw.edu.pl

${ }^{2}$ MSc., Eng., Budimex S.A., ul. Stawki 40, 01-040 Warsaw, Poland, e-mail: przemyslaw.lysiak@budimex.pl

${ }^{3}$ MSc., Eng., Warsaw University of Technology, Faculty of Civil Engineering, ul. Lecha Kaczyńskiego 16, 00-637 Warsaw, Poland, e-mail: r.oleszek@il.pw.edu.pl

${ }^{4}$ DSc., PhD., Eng., Warsaw University of Technology, Faculty of Civil Engineering, ul. Lecha Kaczyńskiego 16, 00-637 Warsaw, Poland, e-mail: w.trochymiak@il.pw.edu.pl 
and the ground investigation, the paper diagnoses and describes the mechanism which led to the emergence of the offsets. Potential patterns of the occurrence of additional settlements, as the reason for emergence of the offsets, were identified and analyzed. The settlement of the outermost support (abutment), as a result of increase of relative density of alluvial sands due to the dynamic interaction of the roadways of Wał Miedzeszyński Street, was analyzed. Analytical and numeric approaches were used in the course of analysis while relying on PLAXIS and MIDAS software.

Keywords: : flyovers, reinforced soil bridge abutments, settlement, offset

\section{INTRODUCTION}

The road flyovers at the place where Trasa Siekierkowska route crosses over Wał Miedzeszyński Street are an element of Warsaw's road infrastructure built in the years $2000 \div 2002$ (Fig. $1 \div 3$ ). The flyovers are three-span structures. The abutment columns are located $43 \mathrm{~cm}$ from the retaining walls which are made of reinforced soil [1], [11]. In the further part of the paper, the outermost columns and the retaining wall made of reinforced soil are called the intermediate reinforced soil abutments. The columns of $\mathrm{P} 1 \div \mathrm{P} 4$ supports (Fig. 2) carry the vertical forces from the spans and the resistance forces in the bearings. RSS walls carry the horizontal forces of the embankment soil and the load of the backfill.

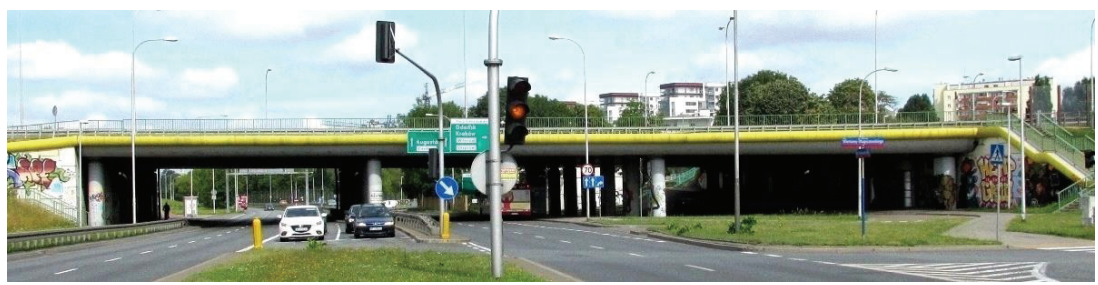

Fig. 1. Side view of Trasa Siekierkowska route's flyovers stretching over Wał Miedzeszyński Street 


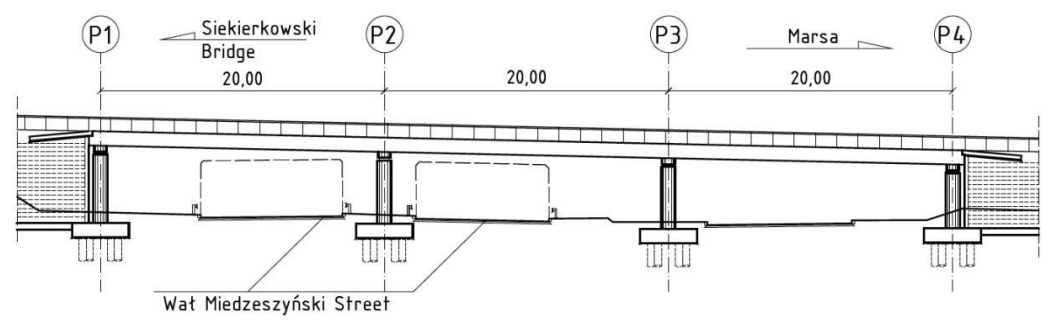

Fig. 2. Side-view drawing of Trasa Siekierkowska route's flyovers stretching over Wał Miedzeszyński Street [1]

The columns rest on rectangular pile caps sitting on two rows of large diameter $(1.0 \mathrm{~m})$ piles bored using steel casing length of a $11.0 \div 15.0 \mathrm{~m}$. The ground surrounding piles (below the cap) consisted of: 0 to $3.0 \mathrm{~m}$ of made ground, 1.0 to $3.0 \mathrm{~m}$ of proglacial lake silty clay, and deep layer of medium or coarse alluvial sands of density index $I_{D}=0.60$. The pile bases in coarse sand with sandy gravel interbedding $\left(I_{d}=0.80\right)$ were cement pressure grouted.

The deformation modules of the soil below a group of piles were determined based on the 2016 site investigations and the Polish Standard [14]. Deformation moduli of $E_{0}=100 \mathrm{MPa}$ for the sands, $E_{0}=$ $33 \mathrm{MPa}$ for the sandy silty clay were derived. Increment of the settlement was calculated using the deformation method for a equivalent foundation block [10]. 
a)

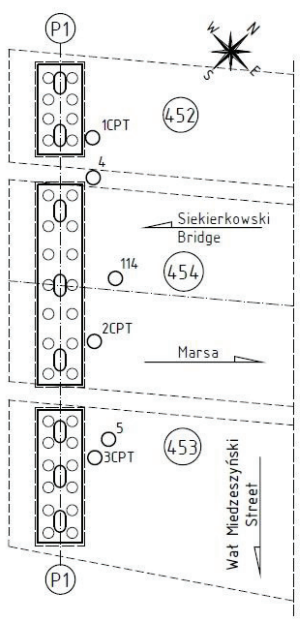

(P1)

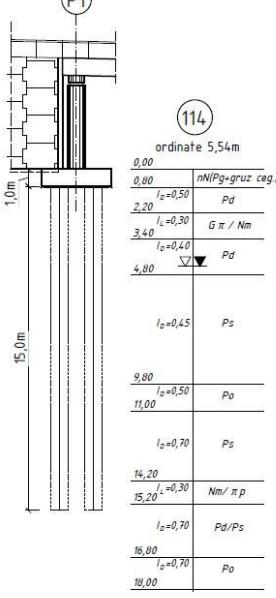

b)
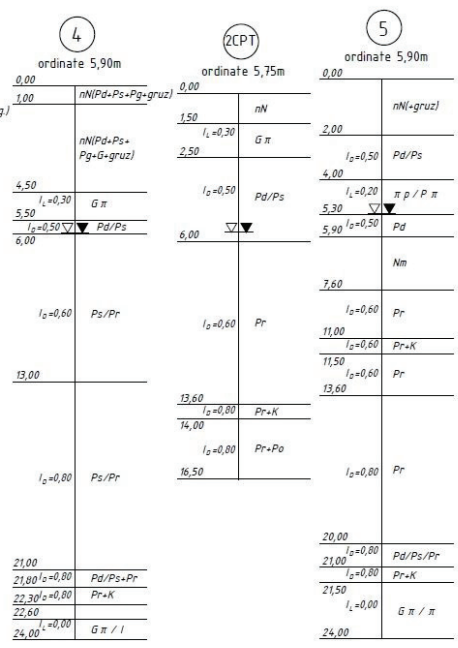

Fig. 3. Comparison of the ground profiles near to the abutment P1; a) location of the boreholes (114 of 1998, 4,5 of 2016) and of the cone penetration tests (1CPT, 2CPT, 3CPT of 2016); b) borehole profiles

In $2015,15 \div 25 \mathrm{~mm}$ offsets $u$ (Fig. 4, 5) were measured above the abutment P1 in the expansion joints, leading to the occurrence of perceptible vibration which accompanied passage of trucks. The offset $u$ was defined as the difference between the levels of the neighboring profiles of one expansion joint (Fig. 4b).

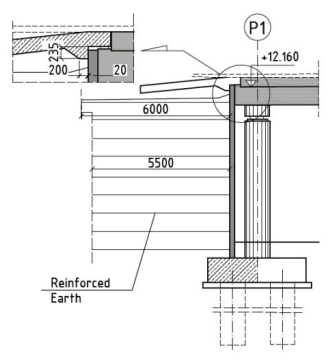

a)

Fig. 4. The abutment P1 [1]; a) a drawing of connection with the approach slab $[\mathrm{mm}]$,

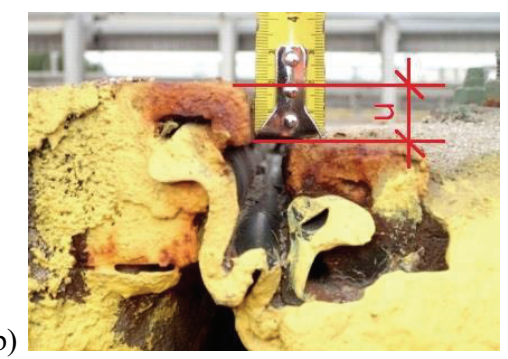

b) view of the offset $u$ (2016) 

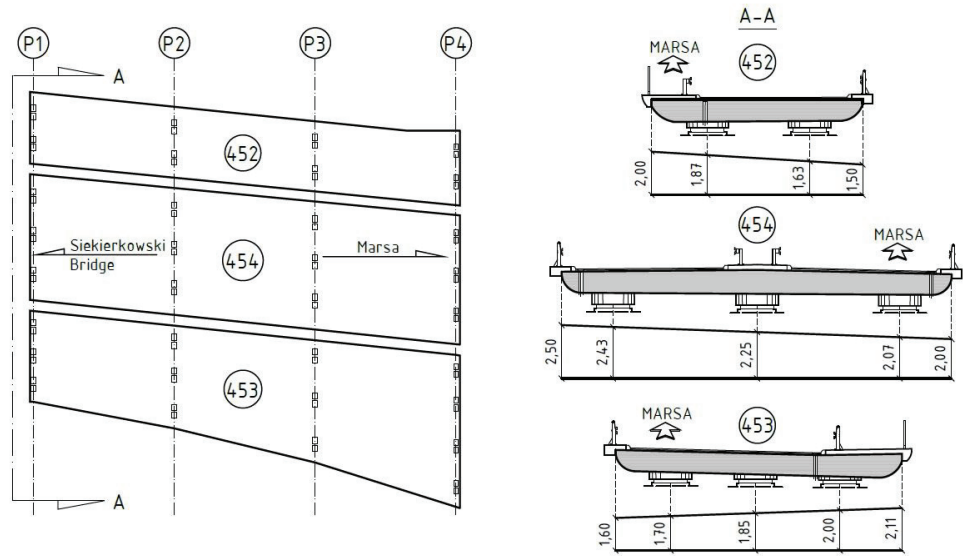

Fig. 5. Superstructures of flyovers [1], [11]; a) plan view of flyovers; b) cross-sections A-A - the measured values of the offset $u[\mathrm{~cm}]$

The observations and the leveling, which were made above the abutment P1 in the years $2015 \div 2016$, demonstrated that a subsiding trough (a local depression) did not appear above the 4.0-meter-long approach slab, as well as along the 8-meter section directly beyond the slab, which could be indicative of settlement of the reinforced soil embankment. No increase of vertical or horizontal displacements was noted during the observations. The results of the analyses of the reason why the offsets emerged were presented while taking into account the observations, the measurements and the historical ground investigations as well as the surveys from the year 2016. Analytical and numerical analyses were applied. Analytical approach was used in the case of a single pile and a group of piles accounting for the results of load tests of the piles, and according to Standard [16], accounting for the effects of the dynamic actions and the limit state stress levels in the reinforced soil. The numerical analyses were made with the use of MIDAS GTX NX (3D) [12] and PLAXIS (2D) [13] software while employing the elastic and plastic model with the Coulomb-Mohr condition. 


\section{ANALYSIS OF THE DISPLACEMENT OF THE SUPPORTS AND THE EMBANKMENT}

\subsection{ASSUMPTIONS AND SCOPE OF THE ANALYSIS}

The purpose of the analysis was to determine and confirm, by means of calculations, the potential reasons of emergence of the offset $u$ above the abutment P1. The occurrence of additional displacements, due to settlement of the abutment in P1 axis and the settlement of the subsoil of the adjacent embankments constructed in reinforced soil technology, was assumed to be the reason behind the emergence of the offset. The column-type supports of the flyovers were placed on large diameter bored piles with injections at the base, where the base and the vast part of the side surface of the pile shafts lay in non-cohesive soil. The following assumptions were made in the analyses:

- settlement of the supports due to permanent loads, during the initial phase of the construction, occurred while the flyover was being erected,

- the expansion joints were installed after the load of the flyover's structure and the embankment were placed on the foundations (with $u=0$ ),

- the occurrence of the offset in the expansion joint results from long-term actions leading to the occurrence of additional soil settlement.

The principal reason causing the offset were the additional settlement of the abutment P1 as a result of the dynamic impact of the traffic, which has led to the increase of the compaction of the mediumdense alluvial sands (with the initial $I_{D}=0.45$ ). Alluvial sands are present in the soil down to the level of $\sim 10 \mathrm{~m}$ below grade (below the ground level) in the immediate vicinity of the abutment P1 (Fig. $2 \div 4$ ). Traffic impact is much more developed for P1 comparing to other piers. This is the result of localization the roadway of Wał Miedzeszyński Street close to the abutment and additional effects generated by heavy vehicles passing expansion joints.

\subsection{SETTLEMENT OF THE OUTERMOST SUPPORT}

\subsubsection{ASSESSMENT OF THE DYNAMIC ACTIONS}

The non-cohesive soils with low density index are susceptible to dynamic effects. Concerns regarding occurrence of such an unfavorable phenomenon were already signaled by the designers of the flyovers in the design documentation [1]. The effects of loosening of the sands when the piles were bored with 
use of a steel casing, and subsequent increase of density of the sands, have not been accounted for the analysis because of the base injections made of the piles [11].

Table 1. List of names and symbols of ground layers (Fig. 3,10)

\begin{tabular}{|c|c|}
\hline PN-B-03020: 1981 [14] & PN-EN ISO 14688-1: 2006 [17] \\
\hline Symbol / Name & Symbol / Name \\
\hline $\mathrm{NN}(\mathrm{nN}) /$ nasyp niebudowlany $\left(\mathrm{P}_{\mathrm{d}}+\mathrm{P}_{\mathrm{s}}+\mathrm{P}_{\mathrm{g}}+\right.$ gruz) & $\mathrm{MSa} /$ Made grounds \\
\hline $\mathrm{P}_{\mathrm{d}} /$ piasek drobny & $\mathrm{MSa} /$ Medium sand \\
\hline $\mathrm{P}_{\mathrm{s}} /$ piasek średni & $\mathrm{clsiSa} /$ clayey silty sand \\
\hline $\mathrm{P}_{\mathrm{g}} /$ piasek gliniasty & $\mathrm{sasiCl} /$ sandy silty clay \\
\hline $\mathrm{G}_{\pi} /$ glina pylasta & $\mathrm{Or} /$ organic soil \\
\hline $\mathrm{Nm} /$ namuły & $\mathrm{grSa} /$ gravelly sand \\
\hline $\mathrm{P}_{\mathrm{o}} /$ pospółka &
\end{tabular}

Additional soil investigations, which were conducted close to the abutment P1 (Fig. 3) in 2016, demonstrated increase of relative density of the medium dense sands as compared to the results of the archival investigations. Due to the use of archival data, the names and the symbols of soil layers in Fig. 3, and in further figures, are presented according to [14]. The list of essential soil layer names, according to [14] and [17], is found in Table 1.

According to the investigations of 2016, the relative density of the medium dense sands increased to the relative density from the initial phase $\left(I_{D} \geq 0.60\right)$. Deeper zones did not change as their density index remained $I_{D}>0.80$.

Based on [8], the empirical criterion of occurrence of densification of sands due to forced vibration is defined by the maximum velocity of vibration, i.e. $V_{\max }[\mathrm{cm} / \mathrm{s}]>I_{D}$. The measurements of the vibration performed in the abutment P1 [1], [11], as generated by the vehicles traveling along Wat Miedzeszyński Street, showed that the biggest vibration acceleration occurs in the vertical direction as trucks and buses drive along the street.

Partial impact of the vibration generated because of uneven surface of the road above the abutment P1 occurs in the form of a surface wave with aperiodic frequency of $10 \div 15 \mathrm{~Hz}$ [1], [11]. The above fact has also been confirmed by the measurement results quoted in [2]. With the surface wave's speed 
of $V_{R} \approx 25 \times 10^{3} \mathrm{~cm} / \mathrm{s}$, the length of the waves $\lambda$ is within $(16 \div 25) \times 10^{2} \mathrm{~cm}$ range. The relative depths of the central part of alluvial sands $z$ underneath the surface of Wał Miedzeszyński Street's roadways (Fig. 3 ) is $z / \lambda \approx 0.30 \div 0.40$, which means that the maximum vertical vibration frequency at such a depth is equal to around $1.1 \mathrm{x}$ of the value measured on the road surface.

The other principal vertical impact affecting the ground under support is the dampened free vibration of the support with the frequency of $2 \div 3 \mathrm{~Hz}$, caused by aperiodic impacts exerted by vehicles.

The maximum velocity of vibration observed during measurements [1], [11], i.e. $V_{\max } \approx 0.8 \mathrm{~cm} / \mathrm{s}>I_{D}$ $=0.45$, meets the requirement related to densification of alluvial sands during the initial period of operation of the flyover. Use of the mean value, i.e. $V_{m}=0.53 \mathrm{~cm} / \mathrm{s}>I_{D}=0.45$ is recommended.

For example, standard values, equal to 0.65 of the maximum values, are used when analyzing the impact of aperiodic vibration caused by earthquakes, which in this case leads to the following requirement: $V_{m}=0.52 \mathrm{~cm} / \mathrm{s}>I_{D}=0.45$ [3]. This estimates confirm the occurrence of the phenomenon of densification of alluvial sands. In the case of vibration generated by road traffic, there occurs interference of many factors whose values are fuzzy, e.g. the condition of the vehicles, the changes of the unevenness of the road surface with time, the frequency of measurements - all of which are difficult to quantify. In the analyzed case the method of assessment recommended in [2] was adopted as well as the geotechnical profiles found in Fig. 2 and the 15-meter piles, as determined based on pile record sheets.

The change of the density of alluvial sands, and hence the reduction of the volume of the soil medium, has been interpreted as the influence of negative friction $T_{n}$ which is conveyed to the flyover's piles. It has been assumed that the phenomenon potentially occurred along the length of the section of the piles located in the "compacted" layers of the non-cohesive soils as well the section passing through the cohesive soils lying above the non-cohesive soils at the time the roadways located on the flyover and beneath it were in operation. The negative friction value was assumed to be the value of the maximum side resistance of the analyzed soils, based on [16]. In the case of the abutment P1, the sequence of layers from the borehole (OW) no. 114 was taken as the reference sequence of layers (Fig. 3). 


\subsubsection{ANALYTICAL ASSESSMENT OF SETTLEMENT OF A SINGLE PILE OF SUPPORT P1}

To assess the impact that the additional load generated by negative friction will have on the settlement of the abutment (P1), an attempt was made to reconstruct the probable "load-settlement" $(Q-s)$ curve which reflects the behaviour of the piles. The analysis was conducted on the basis of assumptions [5], [10]. The forecast included comparison and analysis of the archival results of the load tests on the piles (Fig. 6) of supports P2 (without grouting into the base) and P4 (with grouting into the base), made before the main piling works.

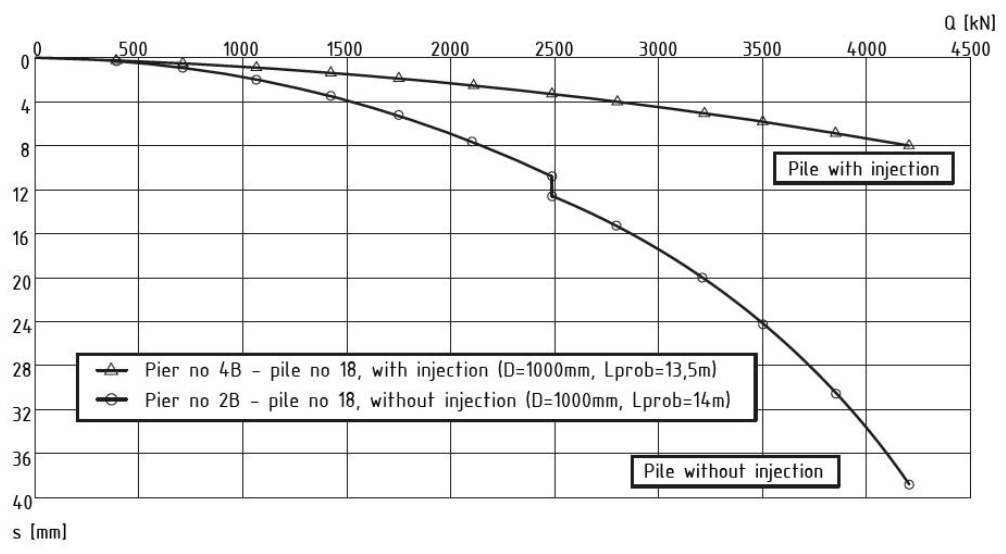

Fig. 6. Load - settlement relation $\left(Q^{-} s\right)[11]$

By interpreting the settlement curves of test piles, estimates were developed as regards the piles' load capacity when calculated in accordance with the basic assumptions [15]. Moreover, the $Q-s$ graphs were recreated for the test piles on the basis of the obtained load capacity results while relying on the assumptions of transformation functions. The effect of elastic shortening of piles was disregarded (it was a small magnitude value - in the case of $\mathrm{C} 25 / 30$ class of concrete, the negative friction load causes pile shaft to be shortened by around $0.1 \mathrm{~mm}$ ). The calibration of the method used to calculate the load capacity of the piles and the determination of the values of function $Q-s$ for the piles located underneath the abutment P1 were made easy since the diameters of all the piles are $100 \mathrm{~cm}$ while the ground conditions are relatively uniform. The difference in the stiffness of the piles, resulting from the grouting into the base, can be noted on the $Q-s$ graphs (Fig. 6). The calibrated stiffness of a pile, 
depending on soil settlement, has been adapted to the ground conditions which are representative in the case of the abutment P1 (Fig. 3), based on OW (borehole) no. 14.

In spite of the grouting having been made all the way to the bases of all piles of abutment P1, as presented in the as-built documentation, the estimates of soil settlement were also developed for the variant without grouting so as to examine the potential effects which could have contributed to the additional settlement of the structure. The analysis indicates that the potential influence that densification of the medium dense sands, resulting from dynamic impacts differs substantially between the piles with injections and the ones without injection into the base. It has been determined that settlement of a pile with and without injection is respectively $3 \mathrm{~mm}$ and $9 \mathrm{~mm}$. An assumption was made that occurrence of an intermediate situation was possible as a result of technological imperfection of the injections and of the piles themselves. For that reason, it is justified to assess the value of the additional settlement, caused by increased the density of the medium/soil, as $6 \mathrm{~mm}$.

Calculations of potential average settlement $s_{g, d}$ of the supports installed on a group of piles, as per (2.1), were conducted to estimate the additional settlement of a single pile.

$$
s_{g, d}=s_{p, d} R_{s r}
$$

where:

$R_{s, r}=2.62$ - the empirical ratio which defines the increase of the settlement of the pile cap sitting on a group of piles vs. a single pile [10], as determined while accounting for the dimensions of the system of piles in the northern support (flyover 452 ) - a group of $2 \times 4$ piles,

$s_{p, d}-$ settlement of a single pile $[\mathrm{mm}]$.

Ultimately the estimated settlement of a group of piles is $s_{g, d}=2.62 \cdot 6 \mathrm{~mm} \approx 16 \mathrm{~mm}$.

\subsection{NUMERICAL ANALYSIS OF SETTLEMENT OF THE GROUP OF PILES FOR THE SUPPORT P1}

Calculations were conducted using the Finite Elements Method (FEM) to verify the settlement of a group of piles caused by permanent load and negative friction. The assumptions which were adopted were analogous as in the case of the estimation performed on the basis of the information obtained 
from test loads. The analysis was conducted developing a 3D spatial model (classes $e^{3}, p^{3}$ ) with the use of MIDAS GTS NX software [12] (Fig. 7).

a)

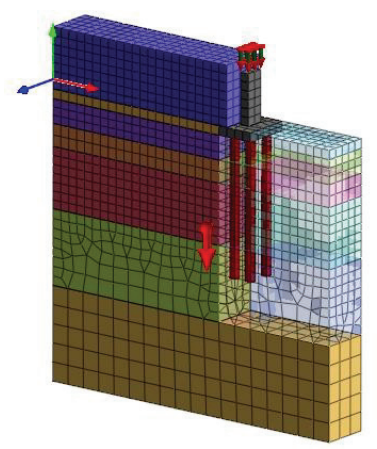

b)

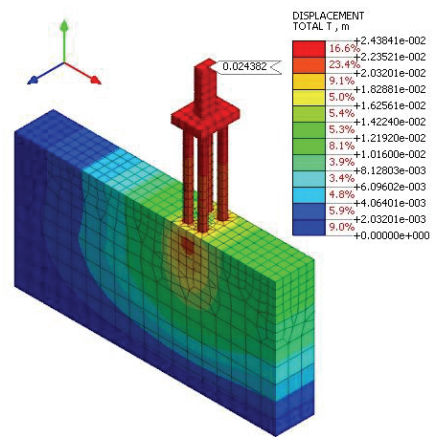

Fig. 7. Calculation model for a group of piles [11]: a) visualization of the model, b) visualization of the exemplary results - total settlement caused by permanent loads and negative friction (red colour denotes maximum values, blue colour denotes minimum values)

Basic dimensions have been adopted in line with the archival documentation while modeling a "section" of the support, consisting of four piles, which represents the central flyover (454), having the width of 5.2 meters with the piles spaced $\sim 2.6 \mathrm{~m}$ apart. The piles were modeled with the class $\left(e^{3}\right)$ elements. Parameters of model, like for example interface between soil and pile elements, were adopted using axisymmetric model calibrated with $(Q-s)$ relation obtained from static loads. Soil parameters were adopted based on the soil investigation of 2016. Force corresponding to the load exerted by four piles was applied to the analyzed "section" of the support. The analysis indicated that potential additional settlement could have occurred under the influence of the analyzed forces. The estimated values of soil settlement that were thus determined were as follows: from permanent loads: $13 \mathrm{~mm}$, from additional loads (negative friction): $\mathrm{s} g, d=12 \mathrm{~mm}$. FEM calculations confirmed the magnitude of the values of settlement, as determined earlier in the analytical approach.

\subsection{NUMERICAL ANALYSIS OF THE DISPLACEMENT OF THE CONNECTION BETWEEN THE EMBANKMENT AND THE STRUCTURE OF THE SUPPORT P1}


The nature of displacements occurring in the reinforced soil embankment was analyzed with the use of MIDAS GTS NX software for comparative purposes [12]. 3D type FES models (Fig. 8, $e^{3}, p^{3}$ classes) and 2D model (Fig. 9b, $e^{2}, p^{2}$ classes) were developed in the plain strain state and for the situation of the load applied to $\mathrm{P} 1$ abutment as the result of $15 \mathrm{~mm}$ displacement.

A section of the support of the central flyover, 454 (Fig. 8), having the width of 5.2 meters, was modeled adopting the basic dimensions from the archival documentation [11]. The system was modeled in two variants (Fig. 8a and Fig. 8b) which differed in terms of the structure of the model, the division into finite elements (meshing) and the method of reconstructing the foundation of the support. Integrated settlement of the support and of the block of ground (located directly under the pile cap, modeld without piles) which was subjected to densification, was adopted in variant 1 . The influence of the block of ground on the surrounding soil was limited by applying contact elements, the so-called interface. No pile modeling was done due to adoption of kinematic boundary conditions. Variant 2 assumed continuous lithological layers and piles as embedded-type elements. Soil parameters were adopted on the basis of soil investigation of 2016. Steel reinforcement of the embankment was modeled as linear elastic type elements + interface. The top layer (the road surface, the base course, the pavement), the barriers, the approach slab) was modeled while using elements with aggregated bigger rigidity than the material of the embankment.

The analysis was also independently conducted in plane strain state (2D) using PLAXIS software [13] and the assumptions which were analogous to the $3 \mathrm{D}$ model so as to verify the results.

Parts of displacement maps (Fig. 9b) form the visualization of the effect of persistence of upper layers of the embankment as compared to the lower levels which settled together with the pile cap due to the additional settlement which was caused, among others, by densification of the soil. The illustrated effect can be described by making an analogy to a cliff. Analysis of the state of the displacement of the embankment at the place where it is connected with the abutment P1, as a result of the additional interactions, points to the possibility of occurrence of a phenomenon involving differences in settlement of the pile cap and the upper layers of the reinforced soil which partly rest on the edge of the pile cap. 
a)

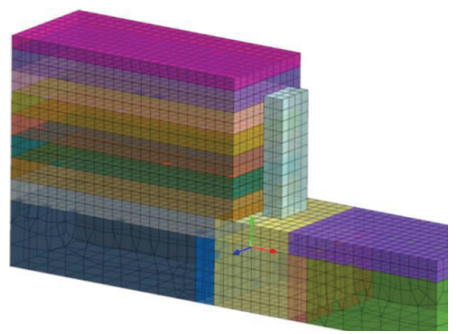

b)

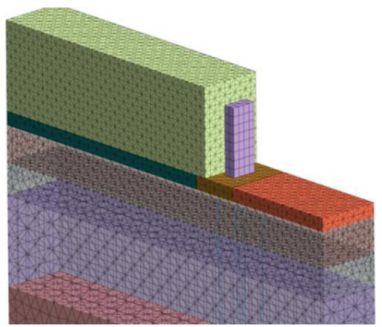

Fig. 8. Visualization of 3D calculation models [11]: a) variant-1, b) variant-2

a)

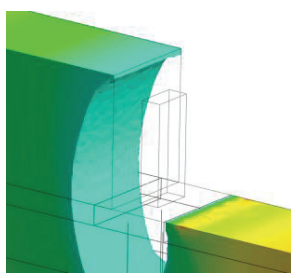

b)

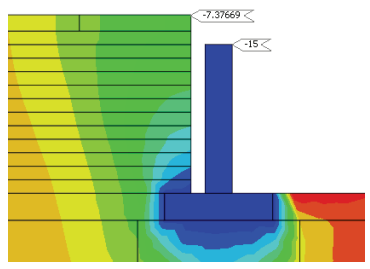

Fig. 9. Examples of the results of the vertical displacement caused by negative friction having the form of forced displacement (settlement of the abutment); a) fragment of 3D model with "cut-out" areas in which the displacement was smaller than occurring at the edge next to the embankment's expansion joint variant-2; b) displacement of the edge of abutment in case of prescribed displacement of pier, plane strain deformation model (2D)

The conducted calculations of various variants of the model, implementation of the loads and introduced restrictions of the interaction demonstrated how complex it is to reconstruct numerically the strict value of the displacement in an offset. The results of the simulation confirmed the possibility of occurrence of difference in terms of the ordinates of the adjacent expansion profiles, depending on the interactions adopted for the analysis, and they confirmed the correctness of the assumptions adopted for the analyzed particular scenario of emergence of the offset. Based on the different variants of the numerical analyses it was confirmed that:

- the analyzed scheme of settlement of the pile cap is probably the dominant factor of the effect of emergence of an offset in the expansion joint, 
- modeling and analysis of the embankment made of reinforced soil, along with the road's structure and the approach slabs, and of the abutment P1 (the intermediate reinforced soil abutments) is a complex issue, however the qualitative interpretation of the obtained results point to the possibility of emergence of diverse displacements on both sides of the expansion joint,

- the analysis did not serve the purpose of quantitative determination of the size of the displacement, however it enabled qualitative assessment and verification of the adopted, potential mechanisms of reactions of the soil.

\subsection{ANALYSIS OF SETTLEMENT OF THE ABUTMENT AND THE EMBANKMENT}

It has been concluded that densification of alluvial sands, resulting from the vibration caused by the vehicular traffic on the roads of Wał Miedzeszyński Street and Trasa Siekierkowska route is the reason of additional settlement of the abutment P1 (on the northern end of the analyzed flyover 452 (Fig. 10) [6]. The geological cross-section adopted for the calculations is illustrated by Fig. 10a.

While accounting for the results of the ground investigation of 2016, two cases were contemplated because of the ambiguity of the geotechnical identification of the layers of the ground forming the subsoil for the group piles:

- presence of proglacial lake silty clay with not drilled thickness,

- lack of sandy silty clay on the assumption that it has been replaced by compact coarse sand (CSa) [11].

The following values of negative friction $\left(T_{n}\right)$ and layer weights $\left(G_{i}\right)$ were obtained, while accounting for water buoyancy:

- made grounds $(\mathrm{Mg}): T_{n}=485.10 \mathrm{kN}, G_{n}=1460.80 \mathrm{kN}$,

- sandy silty clay ( $\mathrm{sasiCl}$ ): $T_{n}=969.60 \mathrm{kN}, G_{g}=70 \mathrm{kN}$,

- medium sand interbedded with fine sand (MSafsg): $T_{n}=9938.50 \mathrm{kN}, G_{g}=1800.40 \mathrm{kN}$.

Medium sand with initial density index of $I_{D}=0.45$ becomes densified, while the soil layers located above, i.e. sandy silty clay and the embankment (Fig. 10), settle [1], [8]. 

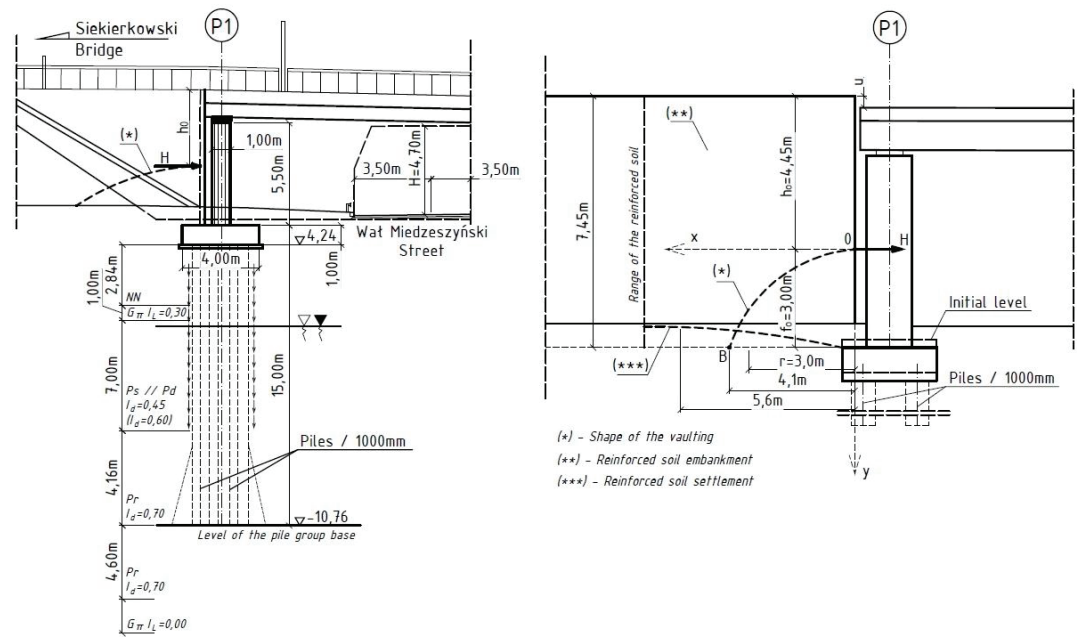

Fig. 10. Analyzed scheme of the abutment P1; a) the geological cross-section; b) outline of the vaulting

The value of the unit negative friction $t$ on the side surfaces of the bored piles, installed with the use of a casing, was determined assuming the original ground level as the $6.03 \mathrm{~m}$ ordinate (the 0 level for Vistula River). Permanent value of $t=10 \mathrm{kPa}$ was assumed in the case of the embankment. The technological coefficients $S_{w}$ were not included while assuming that the soils become densified and are subjected to additional load caused by the horizontal pressure from the embankment. As regards the group of the piles for the abutment P1 of flyover 452, the global value of the negative friction was calculated for each soil layer and the weight of the layers within the area of the pile cap. The global value of the negative friction is $T_{n}=11393 \mathrm{kN}$, while the total weight of the layers is $G=3750 \mathrm{kN}$, with the smaller of the values used for the calculations. The calculations related to the abutment P1 lead to the following characteristic load values for the pile foundation: dead weight and equipment $Q_{n g}=2737 \mathrm{kN}$, live load $Q_{n z}=1939 \mathrm{kN}$. The influence that the live load and the vibration generated by vehicular traffic have on the parameters of the subsoil in which the piles are installed was taken into account while applying the fatigue factors to the deformation modules of pile foundation [7]. In the case of non-cohesive soil, the adopted coefficient was 0.65 , while in the case of cohesive soil it was 0.45 .

Increase of settlement of the abutment as a result of densification of alluvial sands was caused by the live loads and the negative friction. Increase of settlement due to permanent loads also occurred, as a result of increased pressure at the base of a group of piles (Fig. 10) - decrease of the original, 
equivalent area of the base of the group of piles. Increase of pressure in the base of the group of piles was generated by the following factors: negative friction: $125.10 \mathrm{kPa}$; live loads: $64.70 \mathrm{kPa}$; dead weight: $45.70 \mathrm{kPa}$.

Increase of settlement of the flyover's support, in the situation of only sand lying below the base of the group of piles, was calculated using the deformation method and amounted $\Delta_{s l}=12.0 \mathrm{~mm}$. In the case of sandy silty clay $-\Delta_{s}=24.0 \mathrm{~mm}$. The calculated increase of settlement has been considered to be equivalent to the offsets on the expansion joint (Fig. 10b).

The horizontal extent $x_{o}$ of the settlement niche of reinforced soil embankment subsoil, as caused by the offset, was determined on the basis of the edge deflection of the semi-infinite shield of alluvial sands, having the thickness of $7.0 \mathrm{~m}$ and resting on an elastic Winkler subgrade of coarse sand in the FDS (flat deformation state), which is $x_{0} \approx 5.6 \mathrm{~m}$ counting from the outline of the pile group (Fig. 10).

The horizontal extent of the sand densification zone was estimated using the method of geometrical damping in soils [2]. The description of vertical vibration in the dynamics applied for horizontal propagation of waves in the space around a group piles, at any depth, is defined by the equations $(2.2 \div 2.3)$

$$
\begin{aligned}
& w=F(t) \cdot \rho(r), \\
& \dot{w}=\dot{F}(t) \cdot \rho(r)
\end{aligned}
$$

where:

$w$ - vertical displacement, $\dot{w}=V-$ vibration speed, $F(t)$ - the function defining changes of vibration in time $t$, $\rho(r)$ - geometrical damping - a function of change of vibration $w$ during a specified time, dependent on the distance $r$ measured from the side surface of a group of piles on the embankment's side.

It has been assumed that there exists the moment $t_{o}$ in which the amplitude of vibration speeds, at the side surface of a pile group $(r=0)$, will have the maximum value and will be marked as $V_{m, \max }$. Then, the amplitude of vibration speed, as a function of distance, will be defined by means of the following equation (2.4): 


$$
V_{m}=V_{m, \max } \rho(r)
$$

Since in the case of the empirical criterion of densification the speed $V_{m}$ and density index $I_{D}$ are directly related (chapter 2.2.1.), thus the horizontal reach of densification of alluvial sands results from the condition of equality: $I_{D}=0.45$ and $V_{m}=I_{D}=0.53 \rho(r)$. While accounting for the type of soil $\rho(r)=0.4 \div 0.8$ [8], having the corresponding reach of $r / r_{o}=1.3 \div 3.0$, where $r_{o}$ is the equivalent radius of the area delimited by the outline of a pile group. In the case of the analyzed flyover (Fig. $4 \mathrm{a}), r_{o}=2.6 \mathrm{~m}$, and the average horizontal distance from the outline of a pile group to the outer side of the depression niche is around $3.0 \mathrm{~m}$ (Fig. 10b).

The horizontal reach of the densification area will be slightly bigger due to flexural rigidity of the reinforced soil which has been additionally stregthened by the road pavement and the curbs and sidewalk surface. The maximum value of settlement due to the additional densification could be $\approx 30 \mathrm{~mm}$.

Chapter 1 notes that geodesic monitoring of the abutment P1 in the years $2015 \div 2016$ did not demonstrate any changes of the size of the offset. Stabilization of relative density of alluvial sands led to the increase of the base of the equivalent, pile foundation and also of the wave attenuation (absorption of kinetic energy by a mass of soil) by a relative value of around 0.22 to 0.33 . Lack of increase of vertical displacement indicates that the vibration of the support is in the elastic range, which increases its vertical rigidity and the frequency of natural vibration to around $12 \mathrm{~Hz}$.

Vibration measurements [1], [11] demonstrate that the value of the average speed of vibration caused by the traffic on Trasa Siekierkowska Route, following substrate densification, is $V_{m}=0.52 \mathrm{~cm} / \mathrm{s}<I_{D}$ $=0.60$, which confirms stability of densification of alluvial sands. If the effects of the vibration caused by the traffic on Wał Miedzeszyński Street and on Trasa Siekierkowska Route (Fig.. 1 $\div 2$ ) are added up, then the summary maximum vertical speed of vibration will be $V_{m}=0.68 \mathrm{~cm} / \mathrm{s} \approx I_{D}=0.60$. The above result proves that the repeatable, summary impact of vibration can lead to further increase of settlement of the support.

Local differences of reinforced soil settlements initiate emergence of vaulting in the soil (the silos effect). The following have been assumed to calculate the geometry of the vaulting:

$\phi=35^{\circ}-$ the angle of internal friction, $\gamma=19 \mathrm{kN} / \mathrm{m}^{3}-$ dead weight of the soil, 
$c$ - cohesion of soil-and-steel composite as determined according to (2.5),

and galvanized metallic strip with the length of $5.5 \mathrm{~m}$, cross-section of $50 \mathrm{x} 4 \mathrm{~mm}$, anchored four each in every face panel (Fig.11a, Fig. 11b)

$$
c=\frac{0.5 \sigma_{r}(1+\sin \phi)}{\cos \phi}
$$

where:

$\sigma_{r}=23.0 \mathrm{kPa}-$ the ultimate equivalent tensile stress in the soil-and-steel composite, determined based on a local condition of the limit state (slip of the reinforcement in soil along the resistance length 3.4 meters).

The results of the calculations performed using MIDAS software in 2D model (Fig. 9) confirmed that the negative friction around the piles in the reinforced soil embankment may cause the effect of vaulting. In the mechanics of rock formation and masonry the above effects are quite well described with the use of the limit state method in the elastic-and-plastic model. Publication [4] draws attention to the fact that in the case of engineering issues it is the solutions which are close to limit states of the soil that are of practical importance; the model of a free, heavy slope in a limit state [6] (Fig. 11b) was used for the description of the vaulting. The profile of the slope OB is described by the following equations:

$$
\frac{\partial \alpha}{\partial \mathrm{x}}=0, \quad\left(1-\sin \varphi \frac{\partial \sigma}{\partial \mathrm{y}}\right)=\gamma-2 \sigma_{\mathrm{O}} \sin \varphi \frac{\partial \alpha}{\partial \mathrm{x}}
$$

where

$\alpha$ - the angle of inclination of the bigger main stress in respect of axis $x$,

$\sigma, \sigma_{0}-$ accordingly, the mean normal stress at any point and in point $\mathrm{O}$,

$\mathrm{x}, \mathrm{y}-$ co-ordinates.

Finally, upon accounting for the boundary values, the equation describing the OB arching has taken the following form (2.7):

$$
y=\frac{x^{2}}{2 R_{0}}, R_{O}=\frac{3 c}{\gamma} \cos \varphi .
$$


In the analyzed case, the result of the equation describing the vaulting is $y=0.178 x^{2}$. The limit state of stress in the embankment occurs below the critical depth $h_{O}$ (Fig. 10b), as calculated according to the below equation (2.8):

$$
\mathrm{h}_{\mathrm{O}}=\frac{2 \mathrm{c}}{\gamma} \operatorname{tg}\left(45+\frac{\varphi}{2}\right)
$$

In this case $h_{o}=4.4 \mathrm{~m}$, the maximum height of vaulting is $f_{O}=7.4-4.4=3.0 \mathrm{~m}$, while the horizontal span of vaulting $l$ is $4.1 \mathrm{~m}$ (Fig. 10b), which is a smaller value than the length of reinforcement strips $(5.5 \mathrm{~m})$ (see Fig. $4 \mathrm{a})$. The vaulting that emerged caused lack of a local settlement trough underneath and behind the approach slab.

a)

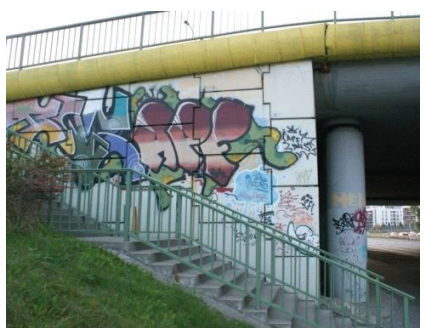

b)

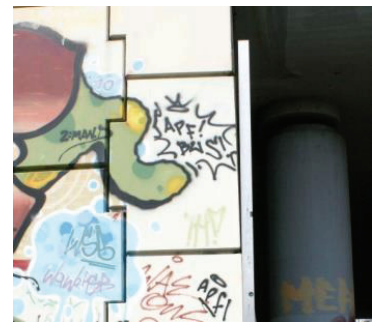

c)

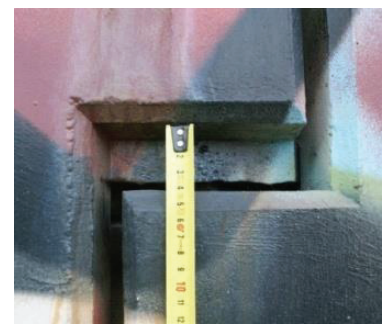

Fig. 11. Examples of deformation of the reinforced soil abutment in the case of the abutment P1: a) side view of the abutment with the curvature of the front wall face; b) detail - the deviation of the front prefabricated facing panels; c) detail - the relative displacement of the prefabricated facing panels

Additional impact of the vaulting:

- unloading of the bottom reinforcement and increase of susceptibility to pulling it out,

- emergence of an additional horizontal force H (Fig. 11b), pushing on the prefabricated face panels, with the force's value being $\mathrm{H} \approx 291 \mathrm{kN} / \mathrm{m}$ at the top of the vaulting.

- The sum of these effects has led to the deformation of the reinforced soil and to moving the face panels longitudinally and transversely in respect of the embankment (Fig. 11).

\section{CONCLUSIONS}

The multi-aspect analysis of various variants of why the displacement of the abutment occurred, resulting in an "offset" emerging in the expansion joint, has confirmed the complexity of the 
examined issue. The numerical values quoted here are of secondary importance, however they have enabled some of the general issues affecting the reinforced soil abutments to be underlined. The pavements of the roads and railways are the source of the vibration which leads to densification of the alluvial sands surrounding the side surfaces of the piles in the abutments of bridges. The effects of soil densification, which emerge during operation of such facilities, can be eliminated by:

- avoiding to rest the prefabricated elements of the panel wall of reinforced soil on the abutment's pile cap (see. Fig. 4a),

- when selecting the piles for the abutments, preference should be given to the displacement piles which compact the alluvial sands,

- so far it has been assumed that reinforcing the substrate with the use of piles or micro-piles installed under the reinforced soil abutments had the purpose of ensuring the sufficient loadcarrying capacity and reducing the settlement: presence of the piling additionally eliminates the development of vaulting in the reinforced soil. Failure to account for the presence of vaulting in the calculations results in uncontrolled displacements of the prefabricated elements of RSS walls.

\section{REFERENCES}

1. M. Bukowski, P. Łysiak, R. Oleszek, W. Trochymiak, "Reasons of Emergence of Differences in Soil Settlement between the Viaduct and the Embankment on Siekierkowska Route", Archives of Institute of Civil Engineering. Ed. Poznan University of Technology, 24/2017, 39-58, ISSN 1897-4007, DOI: 10.21008/j.18974007.2017.24.03 (in Polish).

2. R. Ciesielski, M. Maciąg, „Road vibrations and their influence on buildings”, Copyright by Wydawnictwo Komunikacji i Łączności, Warszawa, 1990. („Drgania drogowe i ich wpływ na budynki”) (in Polish).

3. R. W. Day, „Fundation Engineering Handbook”, Copyright by Mc Graw-Hill Companies, 2010, ISBN 978-007-174009-8.

4. E. Dembicki, "Approximate methods for determining the stress field in the ground in the limit state". Zakład Narodowy Imienia Ossolińskich, Wyd. PAN, Wrocław-Warszawa-Kraków, 1969. („Przybliżone metody wyznaczania pola naprężeń w gruncie w stanie granicznym) (in Polish).

5. K. Gwizdała, A. Krasiński, "Pile foundations, calculations according to Eurocode 7 rules and local experiences", Acta Scientiarum Polonorum. Architectura 15 (2) 2016, 3-22 ("Fundamenty palowe, obliczenia z zastosowaniem zasad Eurokodu 7 i doświadczeń krajowych") (in Polish).

6. A. Jarominiak, "Light retaining structures", Copyright by Wydawnictwo Komunikacji i Łączności, sp. z o.o., Warszawa, 1999. ISBN 83-206-1280-2 („Lekkie konstrukcje oporowe”) (in Polish).

7. M. Kosecki, "Statics of pile structures", PZIiTB, Szczecin 2006 ("Statyka ustrojów palowych" - in Polish).

8. J. Lipiński, ,Foundations for machines”, Copyright by Wydawnictwo Arkady, Warszawa, 1985, ISBN 83-2133265-X (,Fundamenty pod maszyny”) (in Polish).

9. W. W. Sokołowski, "Statika sypučej sredy", Gosudarstwiennoje Izdatielstvo Fizyko-Matematičeskoj Literatury, Moskva, 1960 (in Russian).

10. A. Tejchman and others, "Load Capacity and Settlement of Pile Foundations", Monograph, Gdańsk University of Technology, 2001 ("Nośność i osiadanie fundamentów palowych”) (in Polish).

11. W. Trochymiak, M. Bukowski, P. Łysiak, R. Oleszek and others, „Settlement of bridge structures of the Siekierkowska Route over Wał Miedzeszyński Street”, raport for Municipal Roads Management City of 
Warsaw, Poland, 2016, not published, (“Osiadanie obiektów mostowych Trasy Siekierkowskiej nad Wałem Miedzeszyńskim” - dla Zarządu Dróg Miejskich Miasta Stołecznego Warszawy) (in Polish).

12. MIDAS GTS NX Manuals, Midas IT Co. Ltd, 2016.

13. PLAXIS 2D Manuals, Plaxis bv Delft, 2016.

14. PN-B-03020:1981 Building land. Direct foundation of structures. Static calculations and design (Grunty budowlane. Posadowienie bezpośrednie budowli. Obliczenia statyczne i projektowanie) (in Polish).

15. PN-B-03010: 1983 Retaining walls. Static calculations and design (Sciany oporowe. Obliczenia statyczne i projektowanie) (in Polish).

16. PN-B-02482:1983 Foundations. Bearing capacity of piles and pile foundations (Fundamenty budowlane. Nośność pali i fundamentów palowych) (in Polish).

17. PN-EN ISO 14688-1: 2006. Geotechnical investigation. Identification and classification of soil. Part 1: Identification and description. (Badania geotechniczne. Oznaczenia i klasyfikowanie gruntów. Część 1: Oznaczenia i opis) (in Polish).

\section{LIST OF FIGURES AND TABLES:}

Table 1. List of names and symbols of ground layers (Fig. 3,10)

Tab. 1. Zestawienie oznaczeń i warstw gruntów (rys. 3, 10)

Fig. 1. Side view of Trasa Siekierkowska route's flyovers stretching over Wał Miedzeszyński Street (2016)

Rys. 1. Widok boczny wiaduktów Trasy Siekierkowskiej nad ul. Wał Miedzeszyński (2016)

Fig. 2. Side-view drawing of Trasa Siekierkowska route's flyovers stretching over Wał Miedzeszyński

Street [1]

Rys. 2. Szkic boczny wiaduktów Trasy Siekierkowskiej nad ul. Wał Miedzeszyński [1]

Fig. 3. Comparison of the ground profiles near to the abutment P1; a) location of the boreholes (114 of 1998 , 4,5 of 2016) and of the cone penetration tests (1CPT, 2CPT, 3CPT of 2016); b) borehole profiles

Rys. 3. Porównanie wyników badań podłoża w sąsiedztwie podpory P1; a) lokalizacja otworów badawczych (114 z 1998, 4,5 z 2016) i sondowań (1CPT, 2CPT, 3CPT, z 2016); b) rozpoznane warstwy

Fig. 4. The abutment P1 [1]; a) a drawing of connection with the approach slab [mm], b) view of the offset $u$

Rys. 4. Podpora skrajna P1 [1]; a) schemat połączenia z płytą przejściową [mm], b) ilustracja uskoku $u$

Fig. 5. Superstructures of flyovers [1], [11]; a) plan view of flyovers; b) cross-sections A-A - the measured values of the offset $u[\mathrm{~cm}]$

Rys. 5. Konstrukcje nośne wiaduktów [1], [11]; a) szkic - ukształtowanie wiaduktów w planie; b) przekroje poprzeczne A-A - pomierzone wartości uskoku $u[\mathrm{~cm}]$

Fig. 6. Load - settlement relation $\left(Q^{-} s\right)[11]$

Rys. 6. Wykresy zależności obciążenie - osiadanie $(Q-s)[11]$

Fig. 7. Calculation model for a group of piles [11]: a) visualization of the model, b) visualization of the exemplary results - total settlement caused by permanent loads and negative friction (red colour denotes maximum values, blue colour denotes minimum values) 
Rys. 7. Model obliczeniowy grupy pali [11]: a) wizualizacja modelu, b) wizualizacja przykładowych wyników - osiadania całkowite od obciążeń stałych i tarcia negatywnego (kolor czerwony - wartości max, kolor niebieski - wartości min)

Fig. 8. Visualization of 3D calculation models [11]: a) variant-1, b) variant-2

Rys. 8. Wizualizacja modeli obliczeniowych 3D [11]: a) wariant-1, b) wariant-2

Fig. 9. Examples of the results of the vertical displacement caused by negative friction having the form of forced displacement (settlement of the abutment); a) fragment of 3D model with "cut-out" areas in which the displacement was smaller than occurring at the edge next to the embankment's expansion joint - variant-2; b) displacement of the edge of abutment in case of prescribed displacement of pier, plane strain deformation model (2D)

Rys. 9. Przykłady wyników przemieszczeń pionowych od obciążeń dodatkowych tarciem negatywnym w postaci wymuszonego przemieszczenia (osiadania podpory); a) fragment modelu $3 \mathrm{D}$ z ,wyciętymi” obszarami o przemieszczeniach mniejszych od występujących na krawędzi przydylatacyjnej nasypu - wariant-2; b) model w płaskim stanie odkształceń (2D)

Fig. 10. Analyzed scheme of the abutment P1; a) the geological cross-section; b) outline of the vaulting Rys. 10. Analizowany schemat podpory P1; a) przekrój geotechniczny; b) zarys przesklepienia

Fig. 11. Examples of deformation of the reinforced soil abutment in the case of the abutment P1: a) side view of the abutment with the curvature of the front wall face; $b$ ) detail - the deviation of the front prefabricated facing panels; c) detail - the relative displacement of the prefabricated facing panels

Rys. 11. Przykłady deformacji przyczółka z gruntu zbrojonego podpory P1: a) widok boczny przyczółka z zakrzywieniem lica przedniej ściany; b) szczegół odchylenia od pionu prefabrykatów lica przedniej ściany; c) szczegół rozsunięcia prefabrykatów lica bocznej ściany 


\section{MODELOWANIE I ANALIZA OSIADAŃ POMIĘDZY WIADUKTEM A NASYPEM Z GRUNTU ZBROJONEGO}

Slowa kluczowe: wiadukty drogowe, przyczółki z gruntu zbrojonego, osiadanie, uskok

\section{STRESZCZENIE:}

Rozbudowa infrastruktury komunikacyjnej w Polsce przyczyniła się do wdrożenia różnych technologii budowy obiektów mostowych i poszczególnych ich elementów. Jednym z często stosowanych rozwiązań, od ponad 20 lat, jest zastosowanie gruntu zbrojonego do budowy nasypów, konstrukcji oporowych i przyczółków. Technologię zaproponowaną przez Henri Vidal'a w 1966 roku doceniono również w Polsce niewiele lat później. Jednakże przyczółki mostowe z gruntu zbrojonego zaczęły upowszechniać się w Polsce dopiero na przełomie XX i XXI wieku. Przykładem konstrukcji z tamtego okresu są analizowane obiekty mostowe wybudowane w Warszawie w latach $2000 \div 2002$. Szczególne zainteresowanie autorów dotyczyło podpór skrajnych żelbetowych wiaduktów wybudowanych w postaci przyczółków pośrednich z gruntu zbrojonego. W przyczółkach tych słupy są usytuowane przed licem ściany oporowej i opierają się na prostokątnych oczepach, posadowionych na dwóch rzędach pali wierconych o średnicy $1,0 \mathrm{~m}$ długości $11,0 \div 15,0 \mathrm{~m}$. Pobocznice pali otacza (licząc od spodu oczepu) warstwa nasypów o miąższości $0,0 \div 3,0 \mathrm{~m}$, zastoiskowej gliny pylastej 1,0 $\div 3,0 \mathrm{~m}$, warstwa aluwialnych piasków średnich lub grubych o aktualnym stopniu zagęszczenia $I_{D}=0,60$. Pod stopami pali, które posadowiono w piaskach grubych z przewarstwieniami pospółki o $I_{D}=0,80$, wykonano iniekcję cementową.

W roku 2015 na urządzeniach dylatacyjnych, nad podporą skrajną od strony Wisły, pomierzono uskoki (progi) o wysokości $15 \div 25 \mathrm{~mm}$, które powodowały odczuwalne drgania przęsła wiaduktu towarzyszące przejazdom taboru ciężarowego. Stwierdzono również deformacje bryły gruntu zbrojonego oraz nieregularne przemieszczenia paneli osłonowych w kierunku podłużnym i poprzecznym nasypu. Dostrzeżono także wychylenie prefabrykowanych ścian lica od pionu jak również kilka spękanych prefabrykatów.

Z późniejszych pomiarów wynikało, że nad płytą przejściową i na odcinku 8,0m za płytą nie utworzyła się niecka (lokalne obniżenie), która mogłaby świadczyć o osiadaniu nasypu z gruntu zbrojonego. Nie odnotowano również przyrostu pionowych i poziomych przemieszczeń.

Uwzględniając poczynione obserwacje, pomiary oraz archiwalne i wykonane w 2016 roku badania geotechniczne, analizowano przyczyny powstania uskoku. Podczas analiz stosowano analityczne i numeryczne podejścia obliczeniowe. Analityczne w przypadku pala pojedynczego i grup pali z uwzględnieniem wyników próbnych obciążeń pali oraz według polskich przepisów normowych z uwzględnieniem wpływu efektów dynamicznych i stanu granicznego naprężeń w gruncie zbrojonym. Analizy numeryczne wykonano za pomocą programów MIDAS GTX NX (3D) i PLAXIS (2D) stosując różne modele gruntu, w tym model sprężysto-plastyczny z warunkiem Coulomba-Mohra.

Jako uskok zdefiniowano różnice rzędnych sąsiednich profili dylatacyjnych jednego urządzenia dylatacyjnego. Za przyczynę jego powstania przyjęto wystąpienie dodatkowych przemieszczeń, wynikających z osiadań podpór w osi skrajnej podpory i podłoża dochodzących nasypów zrealizowanych w technologii gruntu zbrojonego. Podpory słupowe wiaduktów zostały posadowione na palach wierconych wykonanych z iniekcją podstawy, gdzie podstawa i większa część pobocznicy pali, znajdują się w gruntach niespoistych. W związku z tym przyjęto założenie, że osiadania podpór, od obciążeń stałych, w początkowej fazie budowy, zrealizowały się na etapie wznoszenia obiektu. Przyjmując, że urządzenie dylatacyjne zostało zamontowane po obciążeniu fundamentów ciężarem konstrukcji wiaduktu i nasypu, to wystąpienie 
uskoku na urządzeniu dylatacyjnym, zinterpretowano jako efekt długotrwałych oddziaływań, przyczyniających się do wystąpienia osiadań dodatkowych. Przyjęto, że zasadniczą przyczyną powodującą wystąpienie uskoku są dodatkowe przyrosty osiadań przyczółków w wyniku oddziaływań dynamicznych od ruchu na jezdni ul. Wał Miedzeszyński, stanowiących o dogęszczaniu się warstw piasków aluwialnych średniozageszczonych, występujących w ośrodku gruntowym do poziomu $\sim 10 \mathrm{~m}$ p.p.t. (poniżej powierzchni terenu).

$\mathrm{W}$ artykule, uwzględniając poczynione obserwacje, pomiary geodezyjne, dostępne badania geotechniczne oraz po przeprowadzeniu wieloaspektowej analizy różnorodnych wariantów powstania przemieszczeń elementów przyczółka, zdiagnozowano i opisano mechanizm powstania uskoku. Przyjęto i analizowano potencjalne schematy wystąpienia przyrostów osiadań jako bezpośrednią przyczynę powstania uskoku. Podane wartości liczbowe mają znaczenie drugorzędne, umożliwiły jednakże uwypuklenie niektórych problemów ogólnych przyczółków obiektów mostowych z gruntu zbrojonego.

Nawierzchnie dróg samochodowych lub kolejowych są źródłem emisji drgań dogęszczających piaski aluwialne znajdujące się wokół pobocznic pali skrajnych podpór obiektów mostowych. Skutki dogęszczania powstające w czasie eksploatacji takich obiektów można eliminować poprzez:

- unikanie oparcia prefabrykatów ścianki osłonowej gruntu zbrojonego na oczepie pali podpory,

- podczas wyboru pali pod podpory skrajne wiaduktów należy preferować pale przemieszczeniowe dogęszczające piaski aluwialne,

- dotychczas przyjmuje się, że wzmacnianie podłoża palami lub mikropalami pod przyczółkami z gruntu zbrojonego ma na celu wyłącznie zapewnić dostateczną nośność oraz redukcję osiadań; obecność pali dodatkowo eliminuje rozwój przesklepień w gruncie zbrojonym. Brak uwzględnienia w obliczeniach obecności przesklepień powoduje nadmierne przemieszczanie prefabrykatów ścianek osłonowych. 